\title{
Correction of Earth Pressure and Analysis of Deformation for Double-Row Piles in Foundation Excavation in Changchun of China
}

\author{
Yijun Zhou, Aijun Yao, Haobo Li, and Xuan Zheng \\ College of Architecture and Engineering, Institute of Geotechnical and Underground Engineering, \\ Beijing University of Technology, Beijing 100124, China
}

Correspondence should be addressed to Yijun Zhou; zyjfcb@126.com

Received 2 February 2016; Accepted 5 May 2016

Academic Editor: Peter Majewski

Copyright (C) 2016 Yijun Zhou et al. This is an open access article distributed under the Creative Commons Attribution License, which permits unrestricted use, distribution, and reproduction in any medium, provided the original work is properly cited.

\begin{abstract}
In order to study the earth pressure and the deformation behavior of the double-row piles in foundation excavation, a large-scale physical model test was introduced to simulate deformation of double-row piles in foundation excavation based on the principle of similarity theory in this paper. Represented by the deep foundation pit engineering of Changchun, the strain and the displacement of the double-row piles and the earth pressure are calculated by the above-mentioned physical model test. Then a numerical simulation has been carried out to validate practicability of the physical model test. The results show that the strain and the displacement of the front-row piles are larger than the back-row piles. The earth pressure of the front-row piles appears to be "right convex," correcting the specification of the earth pressure and putting forward the coefficient of $\beta$. The results in this paper may provide constructive reference for practical engineering.
\end{abstract}

\section{Introduction}

With the development of urbanization in our country, the high buildings and underground engineering have entered a rapid development stage. The mechanical equipment room, commercial space, and garage have been transferred to the underground because of the scarcity of land. The scale of the underground engineering turns to be larger and larger, which makes the design and construction of deep foundation pit harder and harder. As a new type of structure with doublerow piles, it can better solve the stress of the deep foundation pit and solve the influence on surrounding building. The "double-row piles structure" refers to a structure system consisting of two rows of parallel reinforced concrete piles, crown beams, and coupling beam on the top of the piles [1]. Compared to single-row anchored piles, the structure shows better mechanical performance, better holistic nature, smaller construction range, and also smaller influence on surrounding buildings.

At present, double-row piles structure has been used in excavation and slope engineering [2-6]; there are a large number of scholars researching on it. References [7-9] studied the double-row piles in deep foundation pit by using the numerical simulation. References $[10,11]$ studied the related calculation method and the stress mechanism with doublerow piles and made the stress of double-row piles be in accordance with the actual case. References $[12,13]$ researched the stress of the double-row piles by a physical model test and had gotten some beneficial conclusion. However, there are still some problems in the study on double-row piles. Firstly the main study method is numerical simulation, and there are other less methods to validate the result of numerical simulation. Secondly, the key to do the physical model test is not only to meet the geometric similarity, but also to meet other similar physical quantities [14]. The physical model test has gotten some achievement, but it only shrinks the size of the model test and there is no theory to do the model test strictly [15]. Meanwhile there is no relationship between test result and phenomenal nature. Represented by the deep foundation pit engineering of Changchun, this paper mainly researches the stress and displacement of the deep foundation pit by a physical model test. The physical model 
TABLE 1: Physical and mechanical parameters of computational model.

\begin{tabular}{|c|c|c|c|c|c|c|}
\hline Soil name & $\begin{array}{c}\text { Cohesion } \\
(\mathrm{kPa})\end{array}$ & $\begin{array}{c}\text { Internal friction angle } \\
\left({ }^{\circ}\right)\end{array}$ & $\begin{array}{l}\text { Density } \\
\left(\mathrm{kg} / \mathrm{m}^{3}\right)\end{array}$ & $\begin{array}{c}\text { Elastic modulus } \\
(\mathrm{MPa})\end{array}$ & Poisson's ratio & $\begin{array}{c}\text { Thickness } \\
(\mathrm{m})\end{array}$ \\
\hline Miscellaneous fill & 8 & 10 & 1850 & 10 & 0.33 & 2.4 \\
\hline Silty clay & 34 & 14 & 1990 & 22 & 0.35 & 5.6 \\
\hline Full weathered mudstone & 70 & 20 & 1880 & 48 & 0.24 & 5.6 \\
\hline Strongly weathered mudstone & 80 & 20 & 1920 & 60 & 0.23 & 14.4 \\
\hline Weathering mudstone & 100 & 25 & 2290 & 120 & 0.24 & 12 \\
\hline
\end{tabular}

TABLE 2: Physical and mechanical parameters of prototype materials and model materials.

\begin{tabular}{lcccccccccc}
\hline & \multicolumn{3}{c}{ Thickness $(\mathrm{m})$} & \multicolumn{3}{c}{ Elastic modulus (MPa) } & \multicolumn{2}{c}{ Cohesion (kPa) } & \multicolumn{3}{c}{ Internal friction angle $\left(^{\circ}\right)$} & Poisson's ratio \\
& Prototype & Model & Prototype & Model & Prototype & Model & Prototype & Model & Prototype & Model \\
\hline Miscellaneous fill & 2.4 & 0.15 & 10 & 0.6 & 8 & 0.5 & 10 & 0.6 & 0.33 & 0.33 \\
Silty clay & 5.6 & 0.35 & 22 & 1.4 & 34 & 2.1 & 14 & 0.9 & 0.35 & 0.35 \\
Full weathered mudstone & 5.6 & 0.35 & 48 & 3 & 70 & 4.4 & 20 & 1.3 & 0.24 & 0.24 \\
Strongly weathered mudstone & 12.8 & 0.8 & 60 & 3.75 & 80 & 5 & 20 & 1.3 & 0.23 & 0.23 \\
\hline
\end{tabular}

test is produced based on the similarity theory. Then the paper validates the results of the model test by numerical simulation.

\section{Project Overview}

The test takes the soil of Changchun area into consideration. The depth of the excavation is $15.2 \mathrm{~m}$; both length and width are $50 \mathrm{~m}$. There are nine steps to excavate, the first step is to excavate $2.4 \mathrm{~m}$ in depth, and the other steps are all to excavate $1.6 \mathrm{~m}$ in depth. The soil parameters are shown in Table 1.

\section{Model Test}

3.1. Physical Simulation of Soil Parameter Selection. The test takes the soil of Changchun area into consideration. The similarity ratio is $1: 16$ and it is simplified for the prototype soil to facilitate calculation. We select river sand, iron powder, gypsum, and lime as the model soil materials. The miscellaneous fill ratio (volume ratio) of the river sand, iron powder, gypsum, and lime is 1:0:0:0. The silty clay ratio (volume ratio) of the river sand, iron powder, gypsum, and lime is $8: 19: 1: 2$. The soil parameters of weathered mudstone and strongly weathered mudstone are almost the same; therefore the ratio of river sand, iron powder, gypsum, and lime is $8: 19: 1.5: 4$ (Table 2).

3.2. Selection of Model Size. We select the geometrical similarity coefficient according to the size of the model box, and it is about prototype $:$ model $=16: 1$, that is to say, geometric similarity ration $N=16$. The model box length, width, and height are, respectively, about $2 \mathrm{~m}, 1 \mathrm{~m}$, and $2 \mathrm{~m}$. We can come to the conclusion that the pile length is $1600 \mathrm{~mm}$, pile diameter is $50 \mathrm{~mm}$, pile spacing is $100 \mathrm{~mm}$, and row spacing is $150 \mathrm{~mm}$, according to the actual situation and the size of model box. The model test is shown in Figure 1.

The model pile, crown beam, and beam are produced by the gypsum and iron wire. The gypsum simulates C30 concrete, and the steel wire simulates reinforcement six lowcarbon steel wires whose strength is $400 \mathrm{MPa}$ simulated as a model of the 18 HRB400 longitudinal stress bars. Steel wires at the interval of the $400 \mathrm{~mm}$ (strength $400 \mathrm{MPa}$ ) simulate HRB400 stirrups at the interval of $100 \mathrm{~mm}$ (Figure 2).

3.3. Data Acquisition System and Equipment. We get the value of earth pressure by a YT-200 G strain type micro soil pressure gauge, and the soil pressure acquisition system adopts a DH3816N static strain testing system as shown in Figure 3.

3.4. The Test Program. The model test is set up with 18 model piles, the nine rows of every two rows. The numbers of the front-row piles and back-row piles are from $1 \mathrm{~A}$ to $9 \mathrm{~A}$ and from $1 \mathrm{~B}$ to $9 \mathrm{~B}$. After casting model pile layout is shown in Figure 4.

To reduce the influence of the error, the strain gauges are installed on the $4 \mathrm{~A}$ and $4 \mathrm{~B}$ and $6 \mathrm{~A}$ and $6 \mathrm{~B}$ piles. The distance between strain gauge and another one is $200 \mathrm{~mm}$. Constrained by the test conditions, select 7A and 7B arranged pile dial indicator and dial indicator vertical spacing $100 \mathrm{~mm}$, to monitor the pile horizontal displacement. The model test chooses $5 \mathrm{~A}$ and $5 \mathrm{~B}$ number arranged pile earth pressure cells, earth pressure cells vertical spacing $200 \mathrm{~mm}$, to reduce the impact of the surrounding environment on the test results. $5 \mathrm{~A}, 5 \mathrm{~B}, 6 \mathrm{~A}$, and $6 \mathrm{~B}$ represent the number of piles, "one" represents front pile, and "two" represents back-row pile, with numbers from "-1" to "-7" to represent the sensor number. Each sensor position is as shown in Figure 5. 


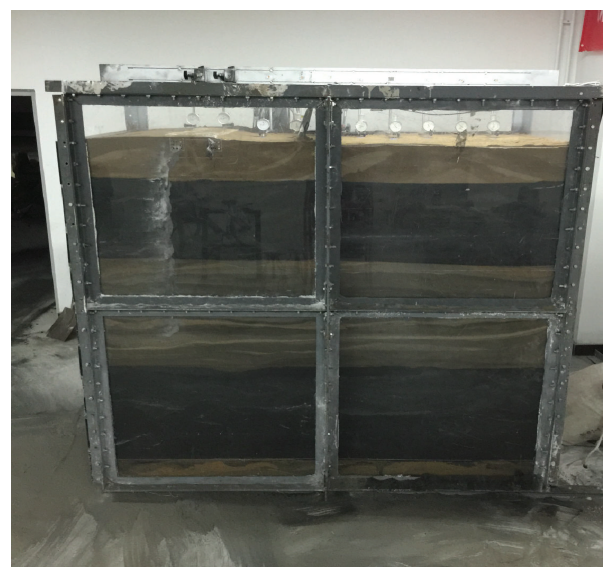

(a)

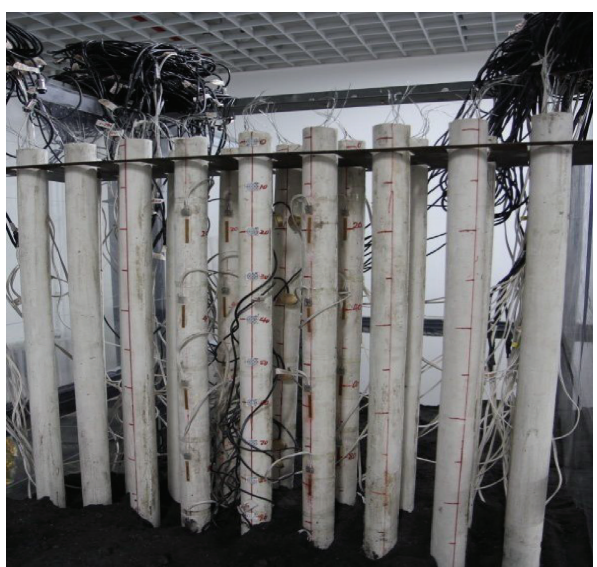

(b)

Figure 1: (a) Test model box and (b) the model double-row piles.

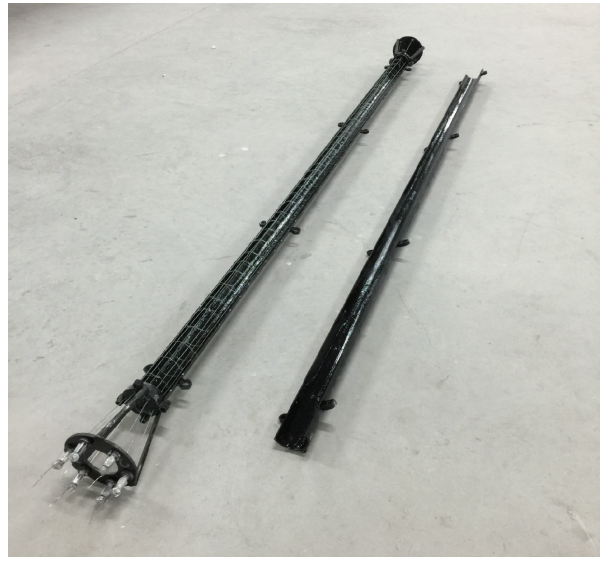

(a)

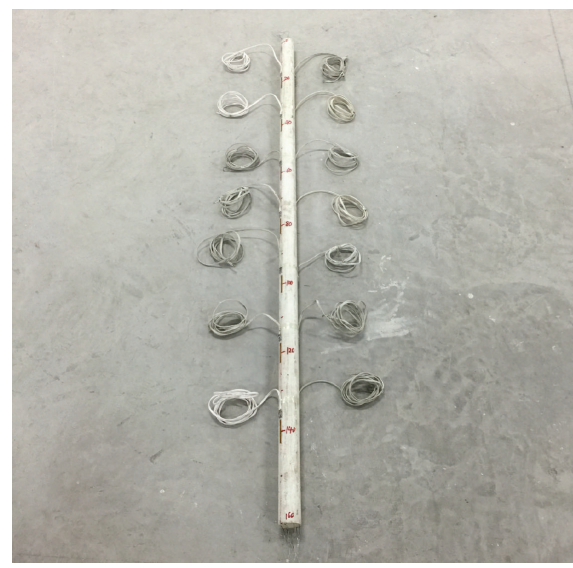

(b)

Figure 2: (a) The model pile template and (b) the model piles.

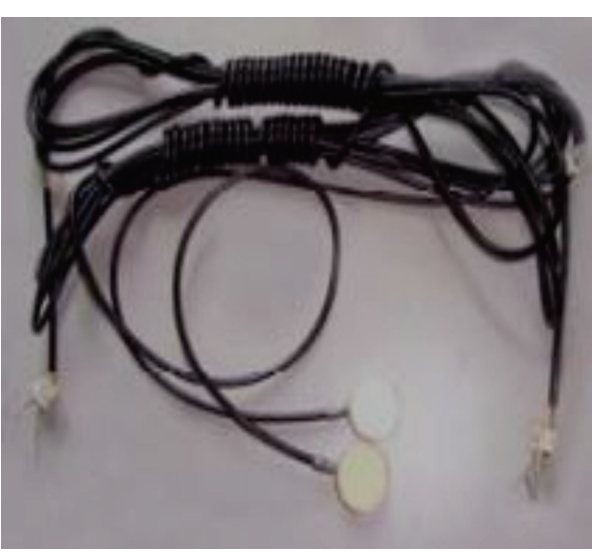

(a)

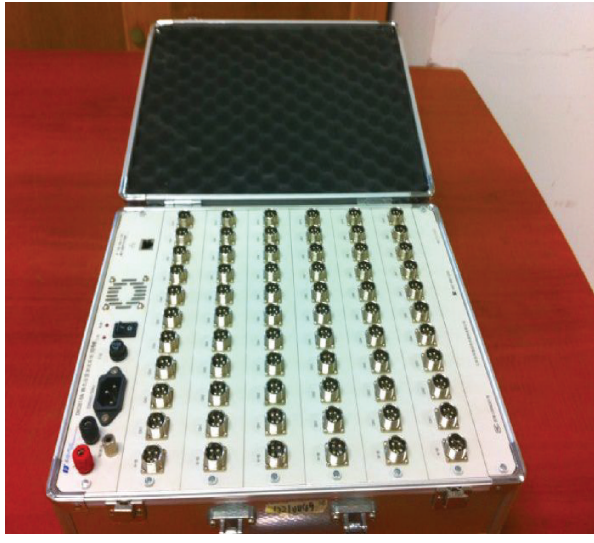

(b)

Figure 3: Data collection system. 


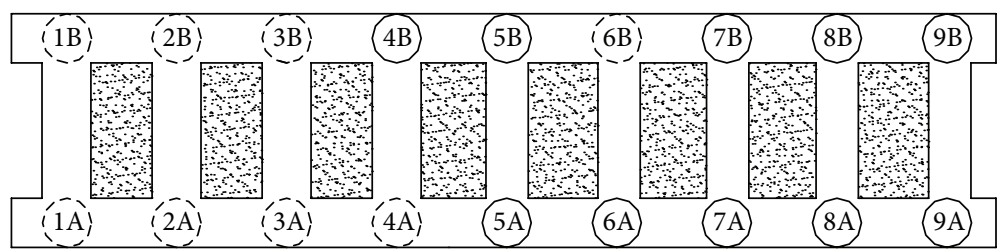

FIgURE 4: Number of double-row piles.
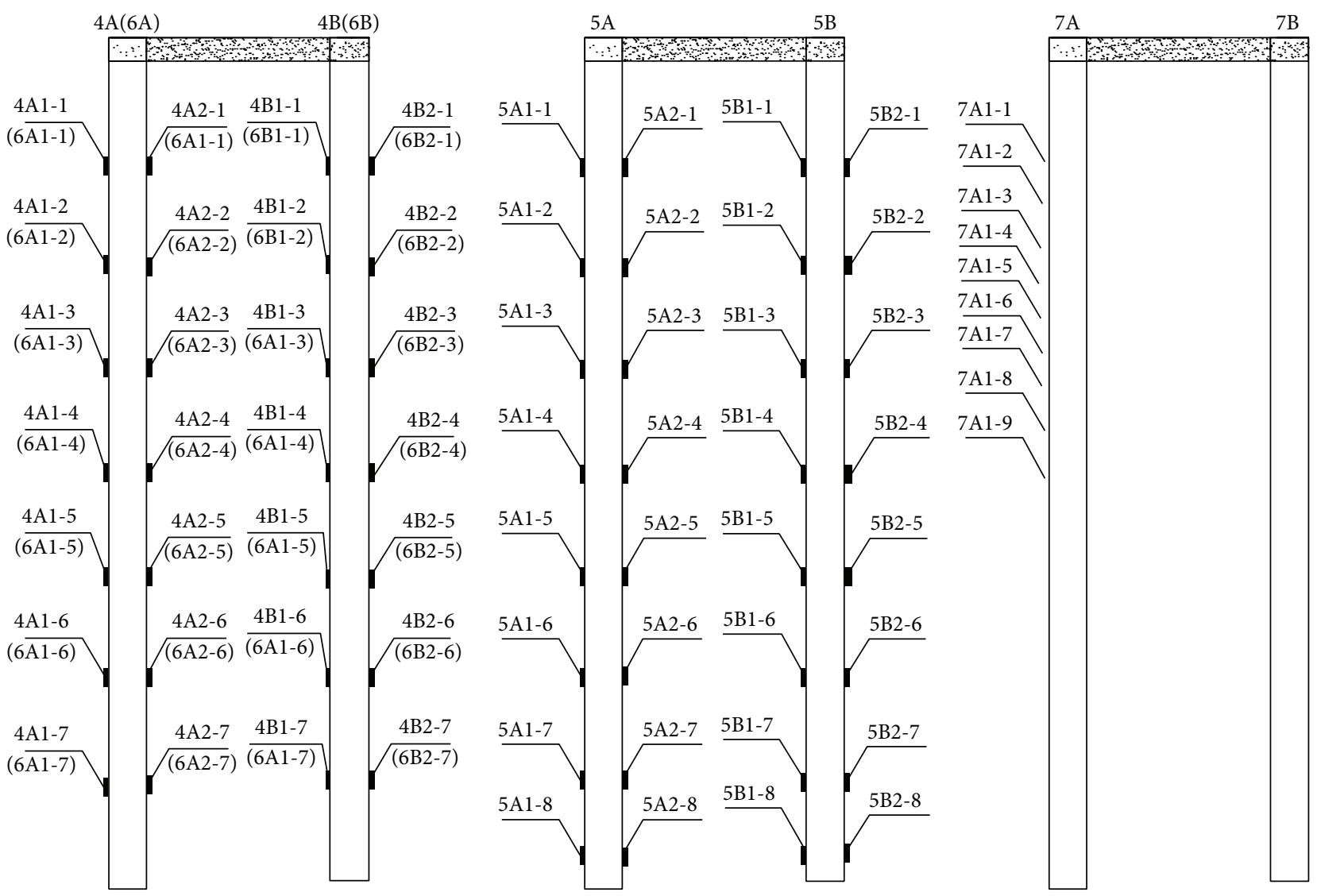

FIGURE 5: Location of strain gauge and dial gauge and earth pressure box.

The deep foundation pit is excavated about $95 \mathrm{~cm}$ in this model test. There are nine excavations in all, and one is excavating $25 \mathrm{~cm}$; the rest are excavating $10 \mathrm{~cm}$. The wall of deep foundation pit is sprayed to reinforce and to simulate concrete pavement in practical engineering. There are nine dial indicators to monitor the pile horizontal displacement. The excavation time interval is 30 minutes each time. The test which is from the beginning to the end is about 50 hours.

\section{Numerical Simulation Analysis}

4.1. Model Material Parameter Selection. In this paper, FLAC 3D finite elements software for numerical simulation is used. The soil elements select Mohr-Coulomb model, selecting piles structure element and beam structure element in the FLAC 3D finite element software, using rigid connection between the piles and beam.

4.2. Finite Element Mesh Model. There is a great influence on the calculation results for the precision degree and the uniformity of meshing. The area of the calculation is about $100 \mathrm{~m} * 100 \mathrm{~m} * 40 \mathrm{~m}$, the length of pile is $25.6 \mathrm{~m}$, the diameter of pile is $0.8 \mathrm{~m}$, the distance between front-row pile and backrow pile is $2.4 \mathrm{~m}$, and the distance between front-row pile and the other adjacent one is $1.6 \mathrm{~m}$ also the same as back-row pile. The width and height of beam are both $0.8 \mathrm{~m}$, as shown in Figure 6. 


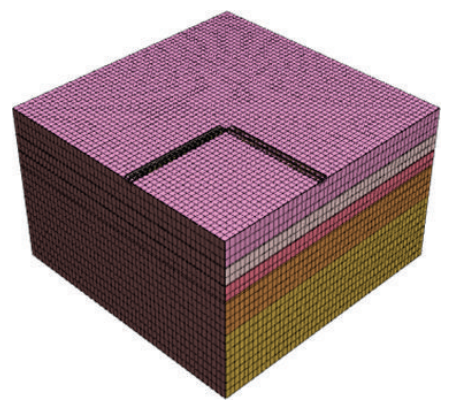

(a)

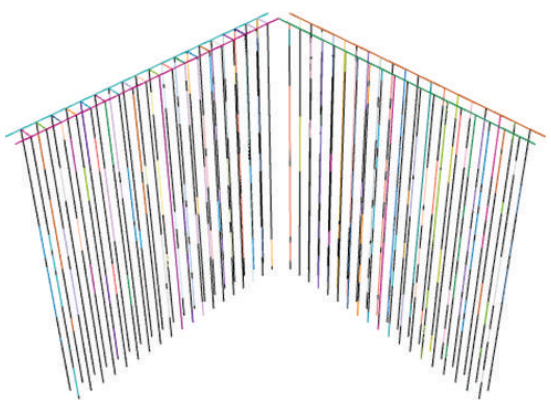

(b)

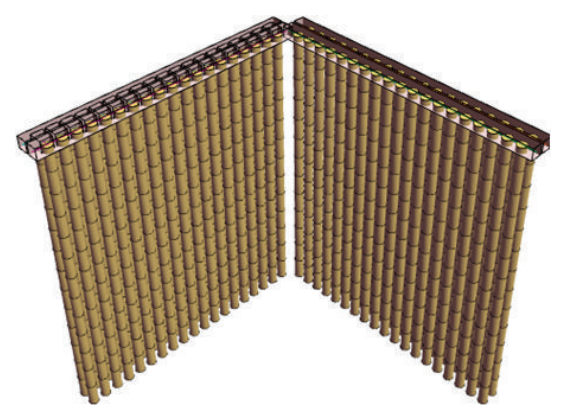

(c)

Figure 6: (a) Finite element mesh model; (b) and (c) the piles-beam model.

4.3. Excavation Process Simulation. In this paper, the null element is adopted to simulate the excavation process; the excavation process is as shown in the following steps:

(1) Establishing the soil numerical simulation model, calculating initial stress field of soil mass under gravity stress, displacement will be reset.

(2) Establishing the double-row piles numerical simulation model, calculating the stress field distribution of double-row pile, displacement will be reset.

(3) Defining the excavation steps, the first step of excavation is $2.4 \mathrm{~m}$, calculating the maximum unbalanced force and the distribution of stress field.

(4) The second step excavation is $1.6 \mathrm{~m}$, calculating the maximum unbalanced force and the distribution of stress field.

(5) Circulate step (4), until the excavation is achieved.

(6) The last step includes calculation and the results reprocessing analysis.

\section{Text Result Analysis}

5.1. Earth Pressure of Front of Front-Row Pile. The model test and the numerical simulation are getting the earth pressure of front of front-row pile by the model test and numerical simulation. There is a maximum earth pressure because of the stress concentration at the bottom of the foundation excavation. Then the earth pressure is more and more smaller as the foundation excavation is deeper and deeper. There is a minimum earth pressure below the bottom of the foundation excavation and the distance to the bottom is $l_{0}$. The value of the numerical simulation and model test is much bigger than the value of the specification. A method of correcting earth pressure for the front of front-row pile is put forward, as shown in formula (1). The value of correcting earth pressure coincides with the value of numerical simulation and model test, as shown in Figure 7:

$$
\begin{aligned}
& p_{s}=\beta\left(k_{s} v+p_{s 0}\right), \\
& \beta= \begin{cases}e^{l_{0}-l} & 0 \leq l \leq l_{0} \\
1 & l_{0}<l \leq l_{d},\end{cases} \\
& k_{s}=m(z-h), \\
& l=z-h, \\
& m=\frac{0.2 \varphi^{2}-\varphi+c}{v_{b}} .
\end{aligned}
$$

5.2. Earth Pressure of Back of Front-Row Pile. As shown in Figure 8 , the value of specification is the same as the value of numerical simulation and model test for the above of the bottom of back of front-row pile. The specification is correct. However the value of the specification below the bottom of back of front-row pile is different from the value of numerical simulation and model test.

Formula (5) for the above of the bottom of back of frontrow pile is put forward, and formula (6) for the below of the bottom of back of front-row pile is put forward:

$$
\begin{aligned}
p_{c} & =k_{c} \Delta v+p_{c o}, \\
p_{c} & =k_{c} \Delta v+p_{a k}, \\
k_{c} & =\frac{E_{S}}{s_{y}-d}, \\
p_{c o} & =\left(2 a-a^{2}\right) p_{a k}, \\
a & =\frac{s_{y}-d}{h \tan \left(45^{\circ}-\varphi_{m} / 2\right)}, \\
p_{a k} & =\sigma_{a k} K_{a i}-2 c_{i} \sqrt{K_{a i}}, \\
K_{a i} & =\tan ^{2}\left(45^{\circ}-\frac{\varphi_{i}}{2}\right) .
\end{aligned}
$$




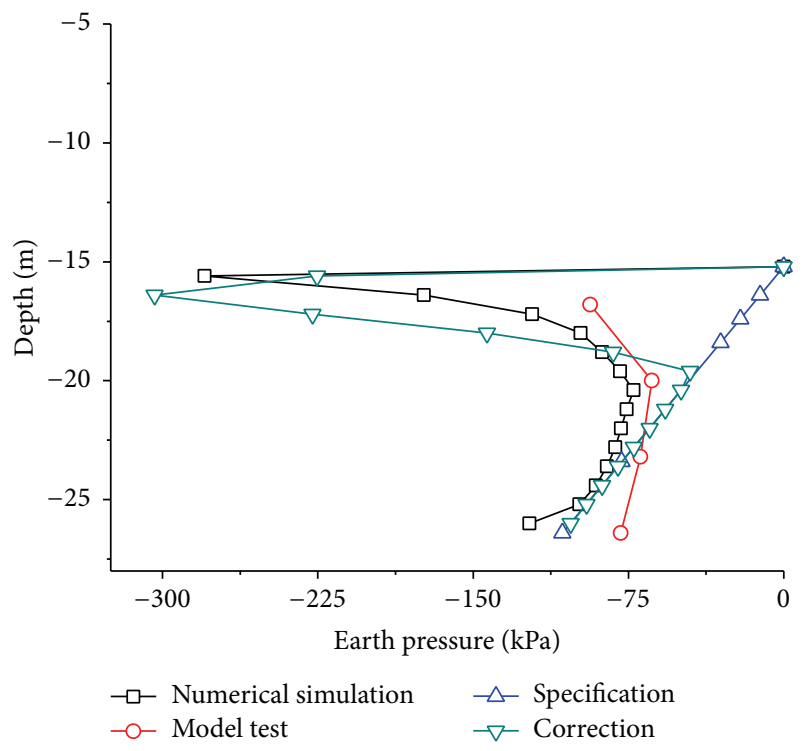

FigURE 7: Earth pressure of front of front-row pile.

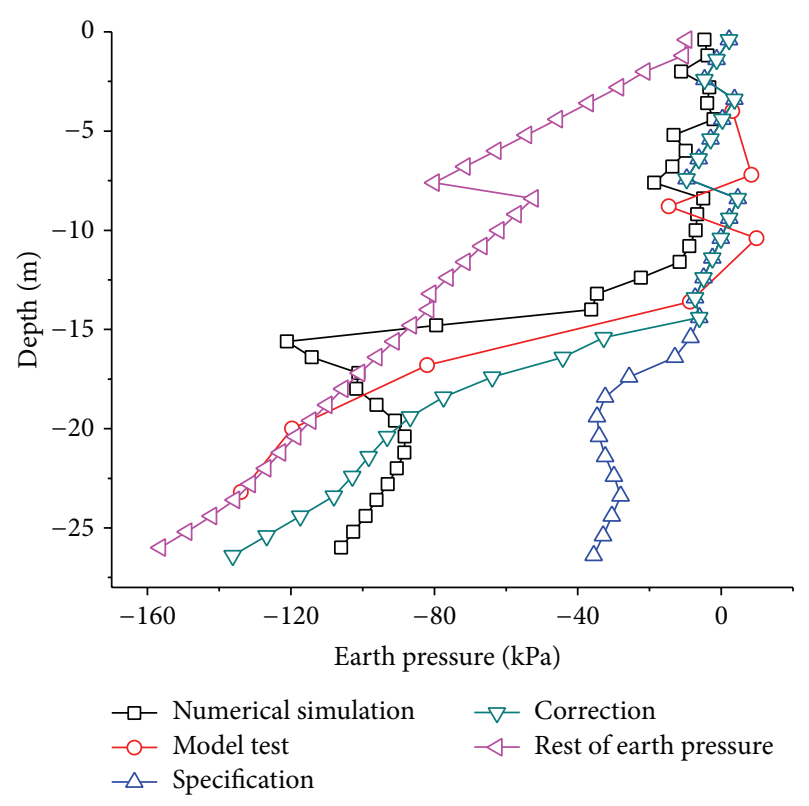

FIGURE 8: Earth pressure of back of front-row pile.

5.3. Earth Pressure of Front of Back-Row Pile. Model test and the numerical simulation are getting the earth pressure of front of front-row pile by the model test and numerical simulation, as shown in Figure 9. The value of specification is the same as the value of the numerical simulation and model test. The calculation model of specification is as shown in Figure 10.

5.4. Pile Displacement Analysis. Compare the displacement of front-row pile and back-row pile as shown in Figure 11. In the numerical simulation, the displacement of the front-row pile is larger than the back-row pile above the bottom of the foundation excavation.

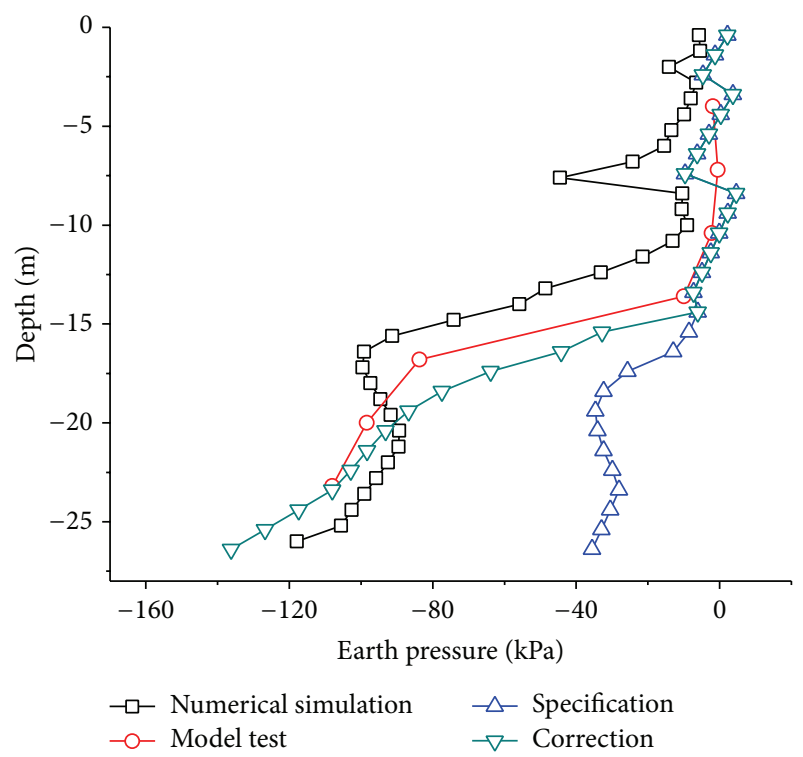

FIGURE 9: Earth pressure of front of back-row pile.

This is because, with loading process of the foundation excavation, there is a free surface of the front-row pile near the foundation excavation so that the displacement of front-row pile is larger than the back-row pile. The largest displacement is under the head of pile about $5 \mathrm{~m}$. The phenomenon has fully proved crown beams connected which are useful for the piles. The minimum displacement is below the bottom of foundation excavation about $2 \mathrm{~m}$. This indicates that the soil has played a significant role for the pile, and the most obvious constraint is at the bottom of foundation excavation.

5.5. Pile Strain Analysis. The numbers of the $4 \mathrm{~A}$ and $4 \mathrm{~B}$ and $6 \mathrm{~A}$ and $6 \mathrm{~B}$ piles are chosen in the model test in order to reduce the accidental factors such as strain gauge error. In this paper, the plus sign indicates axial tension, and the minus sign indicates axial compression.

Both sides of the pile are named "+" that is standard for the tensile. Both sides of the pile are named "-" that is standard for the compression. The front side is named "-" and the back side is named "+" that is standard for the positive bending, and the front side is named "+" and the back side is named "-" that is standard for the negative bending. The pile strain of plus or minus is as shown in Figure 12.

The strain curve of double-row pile model test is as shown in Figures 13 and 14. The strain of $4 \mathrm{~A}$ pile is larger than the $4 \mathrm{~B}$ pile and the same as $6 \mathrm{~A}$. This is because loading the foundation excavation makes the strain of the front pile (4A and $4 \mathrm{~B}$ ) changing, and the strain of back-row pile is much smaller.

In analysis of the pile strain, the front-row pile has negative bending moment above the bottom of the foundation excavation and has the positive bending moment below the bottom of the foundation excavation, because the crown beams and coupling beams have a significant role and there is bending deformation under the earth pressure. The back-row 


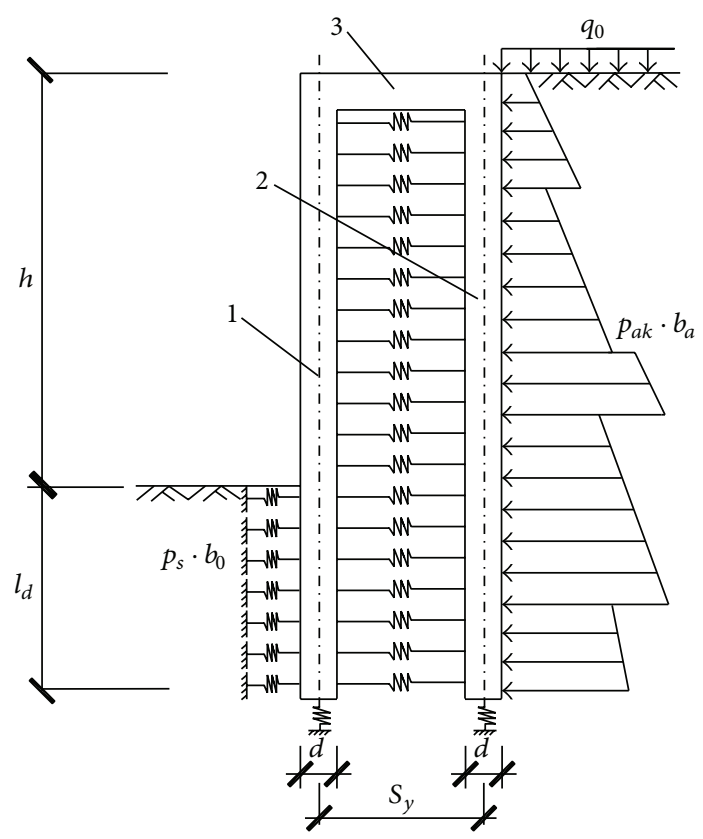

FIGURE 10: Calculation model of the specification of double-row piles.

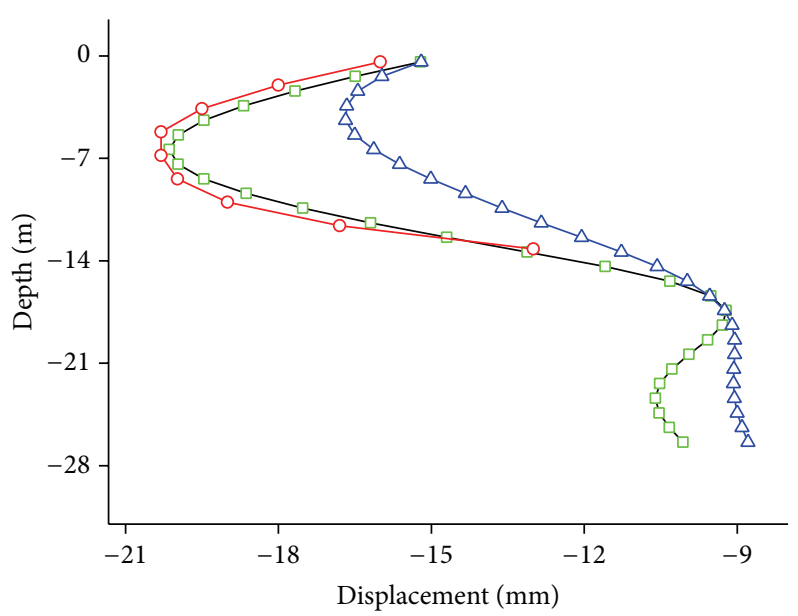

FIGURE 11: Displacement contrast of front-row pile and back-row pile.
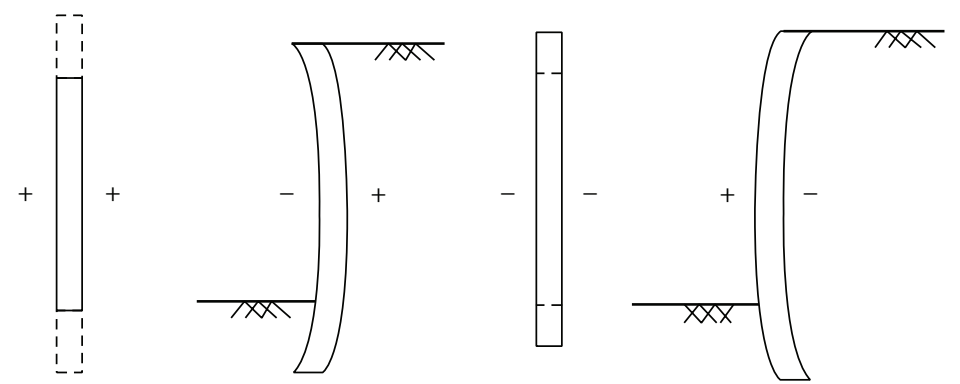

Tensile

Positive bending

Compression

Negative bending

FIgURE 12: The morphology of strain. 

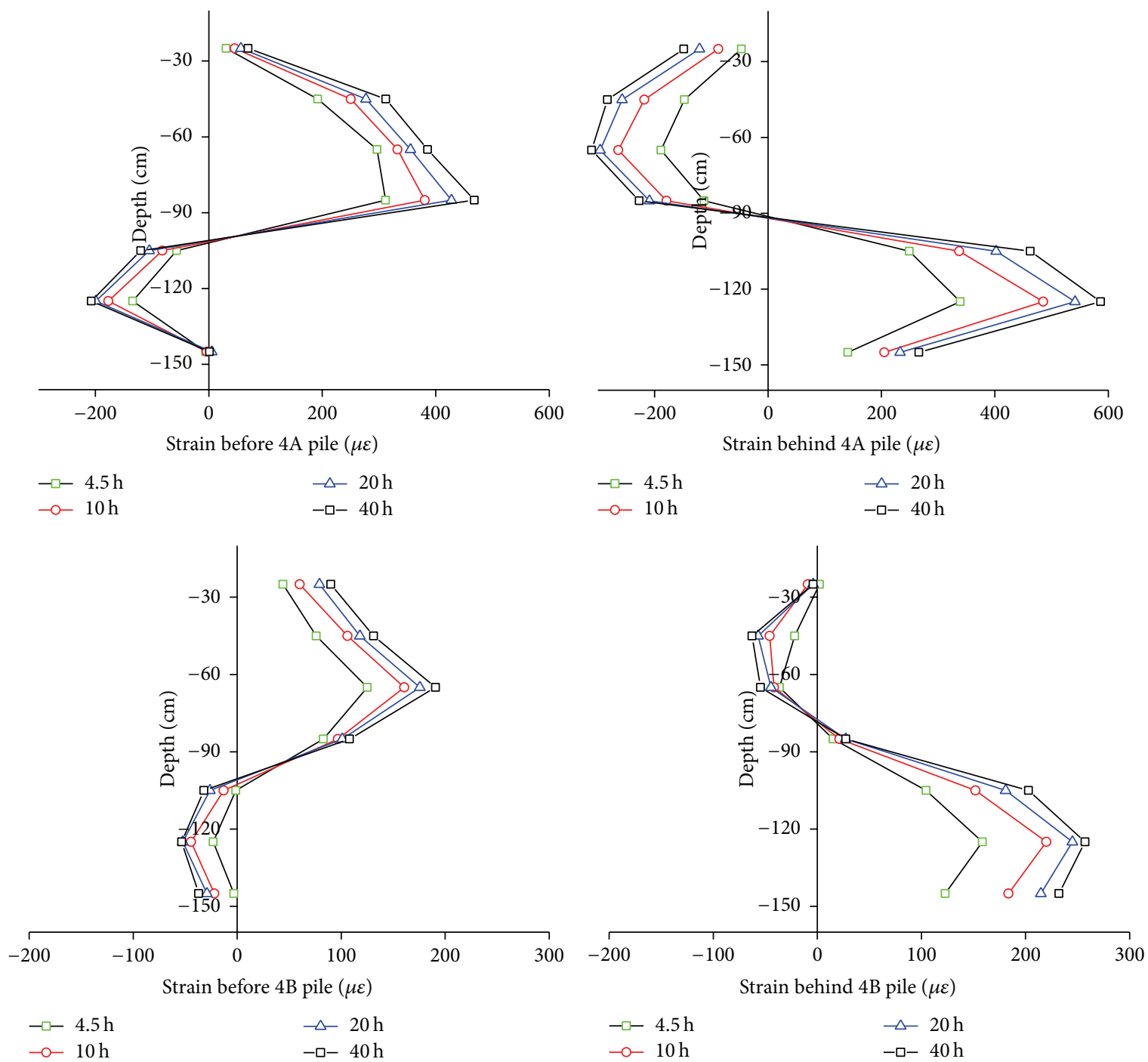

FIGURE 13: The morphology of strain of $4 \mathrm{~A}$ and $4 \mathrm{~B}$.

pile mainly produces tensile strain, only about $10 \mathrm{~cm}$ below the bottom of the foundation excavation which has a positive bent. There is some bent at the bottom of the foundation due to the built-in function. The curve proves that the result of model test is reasonable and reliable.

\section{Conclusion}

(1) The soil pressure of front of front-row piles is much smaller at the depth of $5 \mathrm{~m}$ below the bottom of the foundation excavation, and then the earth pressure appears as a gradually decreasing trend. The earth pressure of back of the frontrow piles is getting larger slowly below the bottom and gets larger quickly at the bottom and reaches a maximum value. The earth pressure of back of the front-row piles shows a changing trend obviously at the soil interface. That is different from Rankine earth pressure theory. The model test and the numerical simulation are basically identical. The coefficient of $\beta$ is reasonable.
(2) The horizontal displacement of front-row piles is obviously bigger than that of the back-row piles above the bottom of foundation excavation. The biggest displacement of the front-row and back-row piles is at depth of $5 \mathrm{~m}$ below the pile head. Because of the built-in function on the pile, the displacement is gradually getting smaller below the bottom of the foundation excavation.

(3) The strain of the front-row piles is larger than that of the back-row piles. The front-row piles mainly bear the earth pressure and have a bending formation. The back-row piles mainly share part of the earth pressure and have a stretching deformation.

\section{Competing Interests}

The authors declare that there are no competing interests regarding the publishing of this paper. 

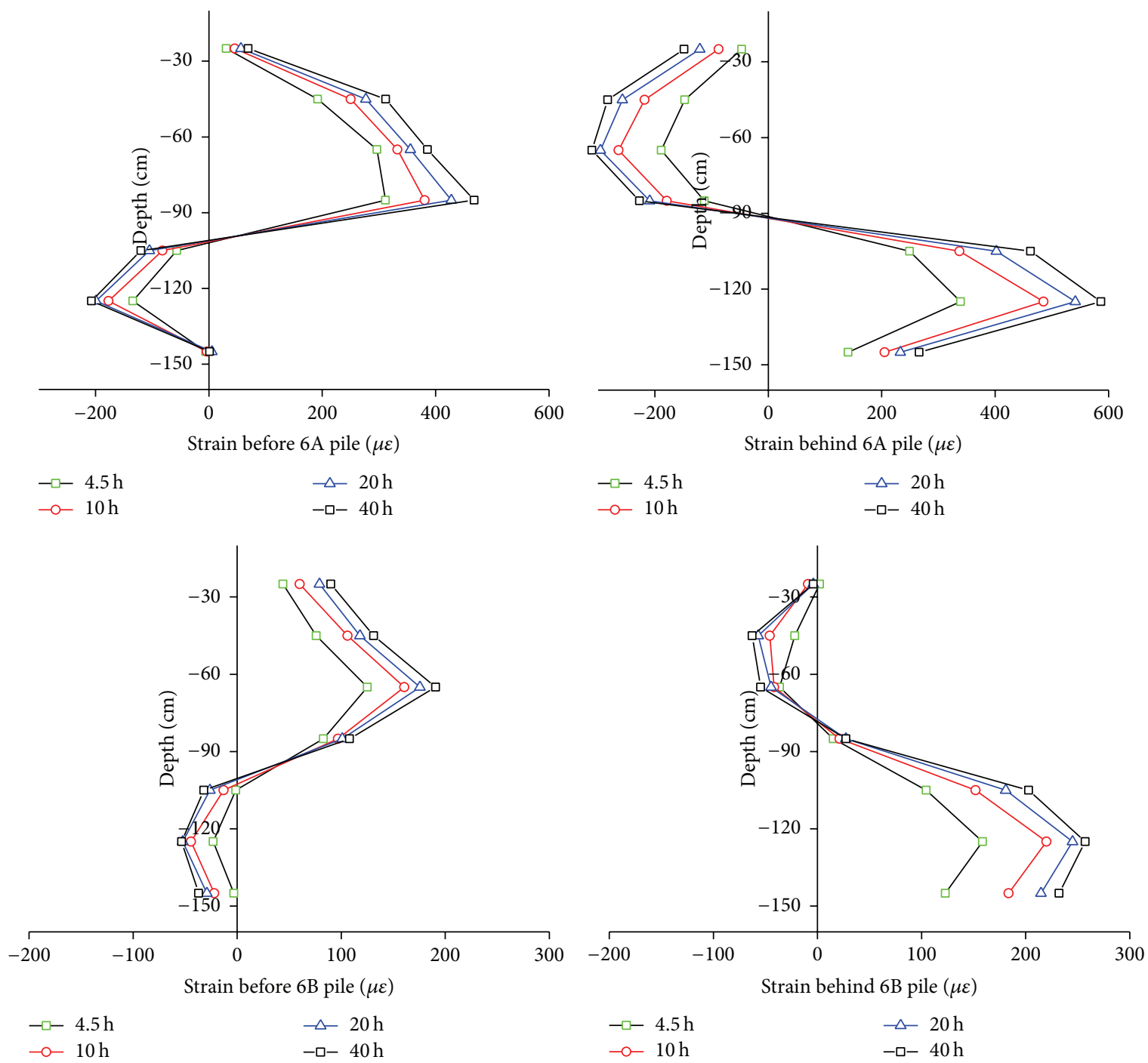

Figure 14: The morphology of strain of $6 \mathrm{~A}$ and $6 \mathrm{~B}$.

\section{Acknowledgments}

The research was supported by the Nation Nature Science Foundation of China (51578023 and 51538001).

\section{References}

[1] H.-W. Ying, Z.-H. Chu, B.-H. Li, and X.-W. Liu, "Study on calculation method of retaining structure with double-row piles and its application," Rock and Soil Mechanics, vol. 28, no. 6, pp. 1145-1150, 2007.

[2] G. Q. Zeng, Design and Analysis of the Forces of Retaining Structure with Double-Row Piles of Deep Foundation Pit, Xian University of Architecture and Technology, Xi'an, China, 2005.

[3] Z. S. Jin and D. Wei, "Discussion on application of double row piles files in Wuhan area," Resources Environment \& Engineering, vol. 24, no. 2, pp. 141-143, 2010.

[4] Q.-K. Nie, J.-M. Hu, and G. Wu, "Deformation and earth pressure of a double-row piles retaining structure for deep excavation," Rock and Soil Mechanics, vol. 29, no. 11, pp. 30893094, 2008.

[5] H.-H. Cui, L.-Q. Zhang, and G.-J. Zhao, "Numerical simulation of deep foundation pit excavation with double-row piles," Rock and Soil Mechanics, vol. 27, no. 4, pp. 662-666, 2006.

[6] F. J. Zhang, Research on Retaining and Protecting Structure with Double-Row Piles, South Jiaotong University, Chengdu, China, 2004.

[7] X. H. Wang, L. Z. Xie, and M. Zhang, "Numerical simulation and characteristic of a double-row piles retaining structure for deep excavation," Journal of Central South University (Science and Technology), vol. 45, no. 2, pp. 596-602, 2014.

[8] S. Q. Cai, Y. Q. Zhao, and S. M. Wu, "FEM analysis of the deep pit excavation with retaining structure of the double piles in soft clay," Journal of Zhejiang University (Science and Technology), vol. 31, no. 4, pp. 442-448, 1997.

[9] G. Zheng, X. Li, and X. F. Gao, "Analysis of double-row piles in consideration of the pile-soil interaction," Journal of Building Structure, vol. 25, no. 1, pp. 99-106, 2004. 
[10] Y. Sun, "Research on calculation method of double-row antisliding structure under sliding surface," Rock and Soil Mechanics, vol. 30, no. 10, pp. 2971-2984, 2009.

[11] Q.-S. Liu and J.-J. Fu, "Research on model and parameters of double-row of piles based on effect of pile-soil contact," Rock and Soil Mechanics, vol. 32, no. 2, pp. 481-494, 2011.

[12] C. Q. Liu, X. Li, and Y. P. Zhang, "Shaking table test and analysis of double row pile retaining structure," China Civil Engineering Journal, vol. 46, no. 2, pp. 190-195, 2013.

[13] X.-C. Li, Y.-M. Men, T. Zhang, H.-J. Liu, and J.-P. Yan, "Experimental study on failure modes for anti-slide piles with a single anchor," Chinese Journal of Geotechnical Engineering, vol. 33, no. 5, pp. 803-807, 2011.

[14] T. Xu, Similar Theory and Model Test, China Agricultural Machinery Press, Beijing, China, 1982.

[15] N. Y. Fan, The Study on the Mechanism of the Retaining Structure with Double-Row Piles in Deep Foundation Pit, Changsha University of Science and Technology, Changsha, China, 2013. 

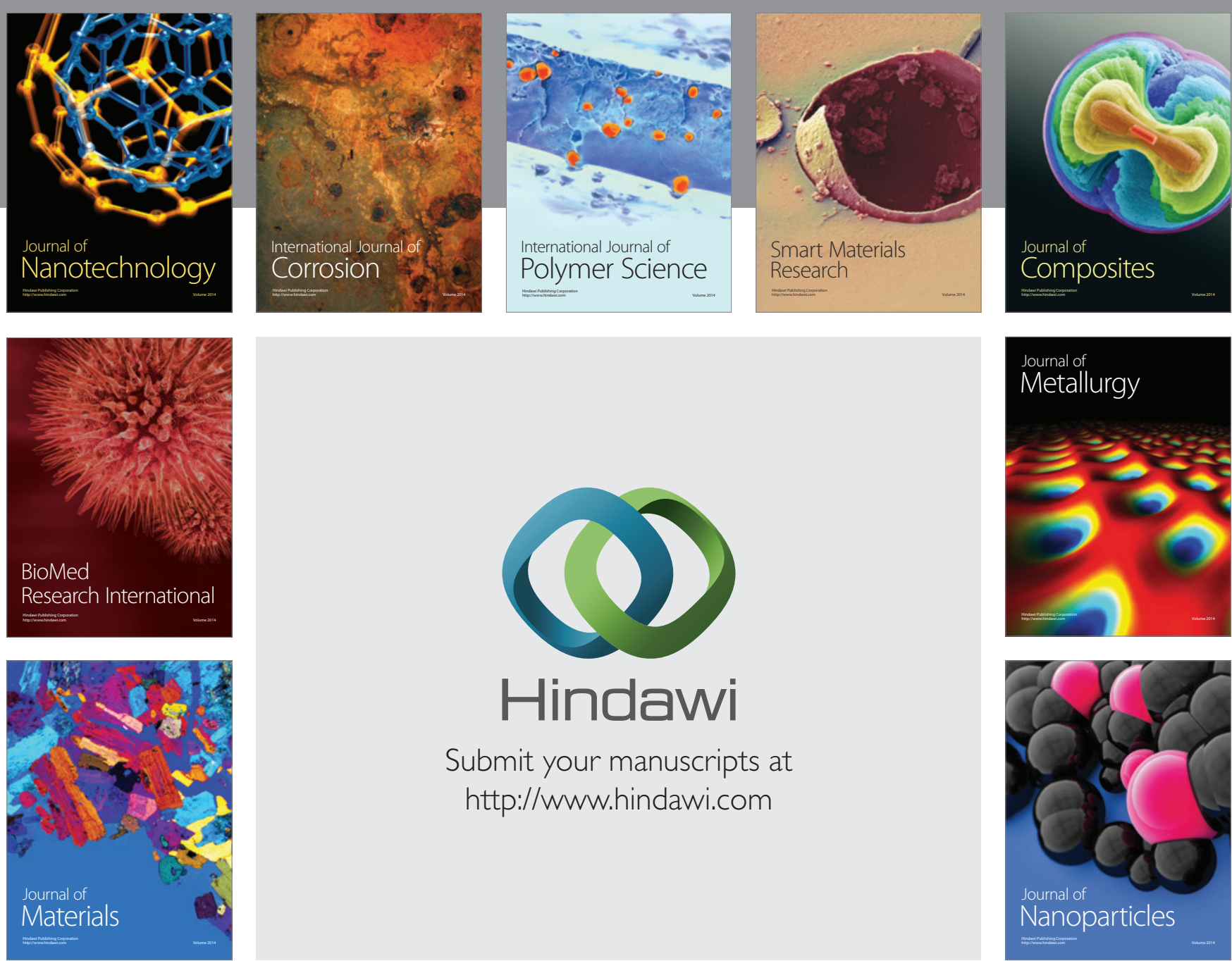

\section{Hindawi}

Submit your manuscripts at

http://www.hindawi.com

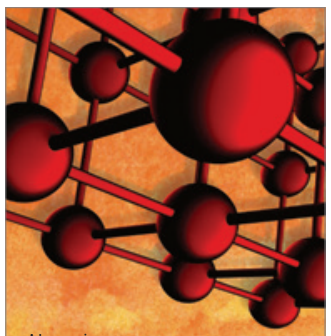

Materials Science and Engineering
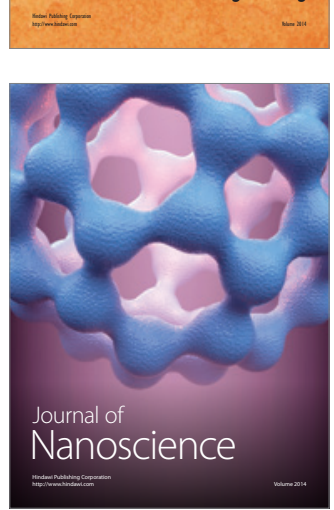
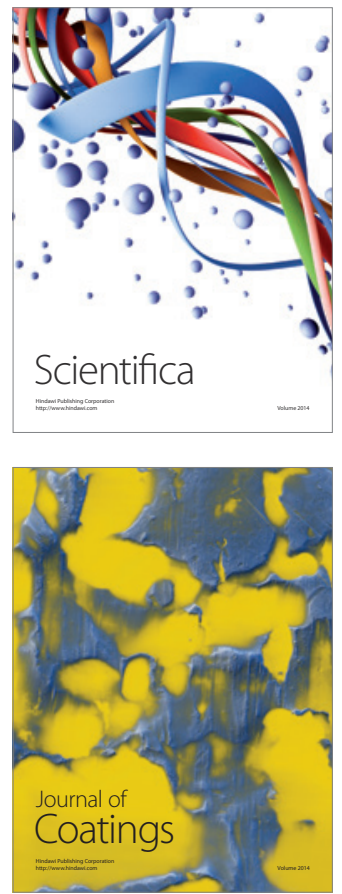
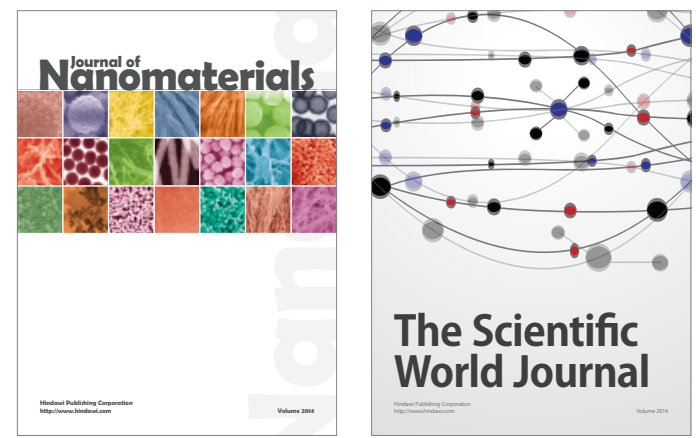

The Scientific World Journal
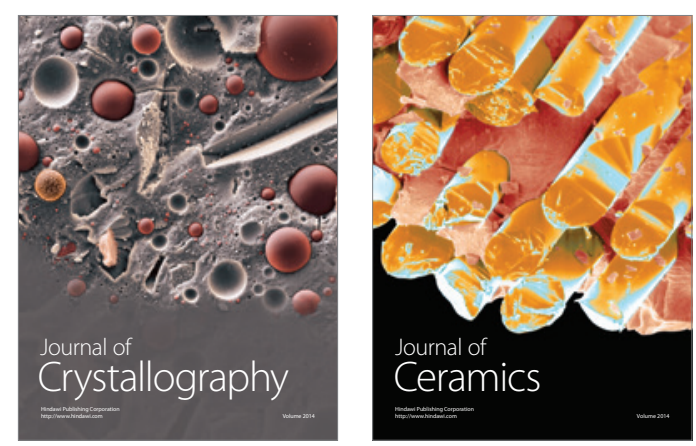
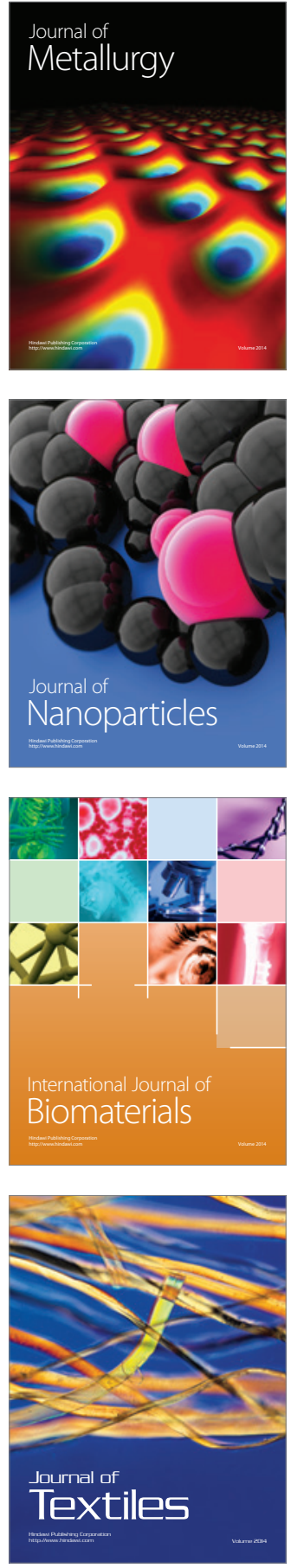